Short Communication

\title{
Leptospiral antibodies in Iberian red deer (Cervus elaphus hispanicus), fallow deer (Dama dama) and European wild boar (Sus scrofa) in Asturias, Northern Spain
}

\author{
Alberto Espí ${ }^{\mathrm{a}, *}$, José Miguel Prieto ${ }^{\mathrm{a}}$, Vanesa Alzaga ${ }^{\mathrm{b}}$ \\ a Servicio Regional de Investigación y Desarrollo Agroalimentario (Principado de Asturias), E-33299 Jove, Gijón, Spain \\ ${ }^{\mathrm{b}}$ Instituto de Investigación en Recursos Cinegéticos (CSIC/UCLM) P.O. Box 535, E-13080 Ciudad Real, Spain
}

\section{A R T I C L E I N F O}

Article history:

Accepted 5 October 2008

\section{Keywords:}

Leptospira spp

Red deer (Cervus elaphus)

Fallow deer (Dama dama)

Wild boar (Sus scrofa)

Serosurveillance

Microscopic agglutination test

\begin{abstract}
A B S T R A C T
Serum samples collected from Iberian red deer (Cervus elaphus hispanicus; $n=472$ ), fallow deer (Dama dama; $n=293$ ) and European wild boar (Sus scrofa; $n=174$ ) in Asturias, Northern Spain, from 1999 to 2005 were examined for antibodies against a reference panel of 14 Leptospira spp. serovars. Positive antibody titres at a microscopic agglutination test cut-off of 1:80 were detected against serovars Pomona (1.6\%, 5.8\%, 5.2\%), Bratislava (1.1\%, 0.7\%, 4.7\%), Grippotyphosa (0.7\%, 2.4\%, 1.7\%), Muenchen ( $2.6 \%, 0 \%$, $0 \%)$, Pyrogenes $(0.4 \%, 2.4 \%, 1.2 \%)$, Panama $(1.2 \%, 1.7 \%, 0 \%)$, Copenhageni $(0 \%, 0.7 \%, 0.6 \%)$, Autumnalis $(0.4 \%, 0 \%, 0.6 \%)$ and Icterohaemorrhagiae $(0 \%, 0 \%, 0.6 \%)$ in Iberian red deer, fallow deer and European wild boar, respectively.
\end{abstract}

(c) 2008 Elsevier Ltd. All rights reserved.
Leptospirosis is a widely distributed zoonotic disease caused by pathogenic serovars of the genus Leptospira. Serological classification of Leptospira spp. divides pathogenic types into antigenically distinct serogroups and numerous serovars. To understand the epidemiology of the disease in a region, it is important to identify the prevalent serovars and their animal hosts.

Iberian red deer (Cervus elaphus hispanicus) and European wild boar are the most important large game species in Spain. Red deer are irregularly distributed on the Spanish mainland, with higher densities in the South-West. Fallow deer (Dama dama) originated from the Mediterranean and have been reintroduced into Spain; currently populations are located in several small isolated areas. Wild boar are more widely distributed.

Previous surveys on leptospirosis in wildlife in Spain have been limited. An early study reported overall seroprevalences of $10 \%$ in European wild boar (Sus scrofa) and 7.2\% in deer in Sierra Morena (Southern Spain) (León-Vizcaíno et al., 1980). The seroprevalence of serovar Pomona in a wild boar population in Montes de Toledo and Sierra Morena (Southern Spain) was 12\% (Vicente et al., 2002). Previous serological studies of Leptospira spp. in domestic animals in Asturias (Northern Spain) showed that Bratislava was the most prevalent serovar (Espí et al., 2000, 2001).

The study area of around $10,565 \mathrm{~km}^{2}$ was in Asturias, located on the North coast of Spain, adjacent to the Cantabrian Sea. The objective of the study was to determine the prevalence of antibodies against 14 Leptospira spp. serovars in three free-ranging species of ungulates in this area.

\footnotetext{
* Corresponding author. Tel.: +34 985 308470; fax: +34 985327811 .

E-mail address: aespi@serida.org (A. Espí).
}

The population sizes were 7000 Iberian red deer in 2003, an average of 1070 fallow deer in 1999-2003 (SIAPA, 2008) and 30628 European wild boar (C. Nores, personal communication). Blood samples were collected from 472 Iberian red deer and 293 fallow deer from 1999-2005 and from 174 European wild boar from 20042005 (Supplementary Table 1), all of which had been hunted.

Sera were screened against a reference panel of 14 leptospiral serovars using the microscopic agglutination test (MAT) (Cole et al., 1973). MAT titres were recorded as the reciprocal of the highest dilution showing 50\% antigen agglutination. Samples giving titres of $\geqslant 1: 80$ were considered to provide evidence of exposure to Leptospira spp. avoiding cross-reactions at lower cut-off titres.

The panel represented the following serovars of Leptospira interrogans: Bratislava (strain Jez Bratislava), Autumnalis (Akiyami A), Bataviae (Van Tienen), Icterohaemorrhagiae (RGA), Pyrogenes (Salinem), Hardjo (Hardjoprajitno), Pomona (Pomona), Grippotyphosa (Moskva V), Copenhageni (M 20) and Muenchen (Munchen C90); Leptospira borgpetersenii: Ballum (S 102) and Castellonis (Castellon 3); and Leptospira noguchii: Panama (CZ 214K) and Louisiana (LSU 1945) genospecies. These reference strains were provided by the Royal Tropical Institute - WHO/FAO Collaborating Centre for Reference and Research on Leptospirosis, Amsterdam, and by the Algete's Central Veterinary Laboratory.

Positive antibody titres at a MAT cut-off of 1:80 were detected against serovars Pomona $(1.6 \%, 5.8 \%, 5.2 \%)$, Bratislava $(1.1 \%, 0.7 \%$, 4.7\%), Grippotyphosa (0.7\%, 2.4\%, 1.7\%), Muenchen (2.6\%, $0 \%, 0 \%$, Pyrogenes (0.4\%, $2.4 \%, 1.2 \%)$, Panama (1.2\%, 1.7\%, 0\%), Copenhageni $(0 \%, 0.7 \%, 0.6 \%)$, Autumnalis $(0.4 \%, 0 \%, 0.6 \%)$ and Icterohaemorrhagiae $(0 \%, 0 \%, 0.6 \%)$ in Iberian red deer, fallow deer and European wild boar, respectively (Table 1 ). Serovar Pomona was predominant 
Table 1

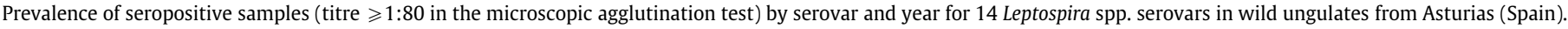

\begin{tabular}{|c|c|c|c|c|c|c|c|c|c|}
\hline Species/year & Bratislava & Autumnalis & Icterohaemorrhagiae & Pyrogenes & Pomona & Grippotyphosa & Copenhageni & Muenchen & Panama \\
\hline \multicolumn{10}{|c|}{ Iberian red deer } \\
\hline 1999 & $1 / 90(1.1)^{a}$ & $1 / 90(1.1)$ & $0 / 90$ & $1 / 90(1.1)$ & $0 / 90$ & $0 / 90$ & $0 / 90$ & $0 / 90$ & $0 / 90$ \\
\hline 2000 & $0 / 40$ & $0 / 40$ & $0 / 40$ & $0 / 40$ & $0 / 39$ & $1 / 39(2.5)$ & $0 / 39$ & $1 / 39(2.6)$ & $0 / 39$ \\
\hline 2001 & $2 / 101(2.0)$ & $0 / 101$ & $0 / 101$ & $0 / 101$ & $1 / 91(1.0)$ & $0 / 91$ & $0 / 91$ & $0 / 91$ & $3 / 91(3.1)$ \\
\hline 2002 & $1 / 111(0.9)$ & $1 / 111(0.9)$ & $0 / 111$ & $0 / 111$ & $1 / 91(1.1)$ & $0 / 91$ & $0 / 91$ & $6 / 91(6.6)$ & $1 / 91(1.1)$ \\
\hline 2003 & $1 / 50(2.0)$ & $0 / 50$ & $0 / 50$ & $1 / 50(2.0)$ & $2 / 36(4.0)$ & $1 / 36(2.0)$ & $0 / 36$ & $3 / 36(6.0)$ & $0 / 36$ \\
\hline 2004 & $0 / 46$ & $0 / 46$ & $0 / 46$ & $0 / 46$ & $2 / 47(4.2)$ & $1 / 47(2.1)$ & $0 / 47$ & $1 / 47(2.1)$ & $0 / 47$ \\
\hline 2005 & $0 / 33$ & $0 / 33$ & $0 / 33$ & $0 / 33$ & $1 / 33(3.0)$ & $0 / 33$ & $0 / 33$ & $0 / 33$ & $1 / 33(3.0)$ \\
\hline \multicolumn{10}{|l|}{ Fallow deer } \\
\hline 1999 & $0 / 59$ & $0 / 59$ & $0 / 59$ & $4 / 59(6.8)$ & $0 / 57$ & $3 / 57(5.3)$ & $0 / 57$ & $0 / 57$ & $0 / 57$ \\
\hline 2000 & $0 / 43$ & $0 / 43$ & $0 / 43$ & $0 / 43$ & $0 / 43$ & $3 / 43(7.0)$ & $1 / 43(2.3)$ & $0 / 43$ & $0 / 43$ \\
\hline 2001 & $0 / 42$ & $0 / 42$ & $0 / 42$ & $0 / 42$ & $0 / 42$ & $1 / 42(2.4)$ & $0 / 42$ & $0 / 42$ & $4 / 42(9.2)$ \\
\hline 2002 & $0 / 33$ & $0 / 33$ & $0 / 33$ & $0 / 33$ & $0 / 33$ & $0 / 33$ & $1 / 33(3.0)$ & $0 / 33$ & $1 / 33(3.0)$ \\
\hline 2003 & $2 / 36(5.5)$ & $0 / 36$ & $0 / 36$ & $0 / 36$ & $0 / 36$ & $0 / 36$ & $0 / 36$ & $0 / 36$ & $0 / 36$ \\
\hline 2004 & $0 / 59$ & $0 / 59$ & $0 / 59$ & $3 / 59(5.1)$ & $9 / 59(15.2)$ & $0 / 59$ & $0 / 59$ & $0 / 59$ & $0 / 59$ \\
\hline 2005 & $0 / 18$ & $0 / 18$ & $0 / 18$ & $0 / 18$ & $8 / 21(38.1)$ & $0 / 21$ & $0 / 21$ & $0 / 21$ & $0 / 21$ \\
\hline \multicolumn{10}{|c|}{ European wild boar } \\
\hline 2004 & $6 / 89(6.7)$ & $1 / 89(1.1)$ & $1 / 89(1.1)$ & $1 / 89(1.1)$ & $4 / 92(4.3)$ & $1 / 92(1.1)$ & $0 / 92$ & $0 / 92$ & $0 / 92$ \\
\hline 2005 & $2 / 82(2.4)$ & $0 / 82$ & $0 / 82$ & $1 / 82(1.1)$ & $5 / 82(6.1)$ & $2 / 82(2.4)$ & $1 / 82(1.1)$ & $0 / 82$ & $0 / 82$ \\
\hline
\end{tabular}

a Number positive/number tested (\% positive).

among fallow deer (5.8\%) and European wild boar (5.2\%), while serovar Muenchen was most frequent among Iberian red deer (2.6\%). Titres of antibodies for different leptospiral serovars ranged from 1:80 to 1:2560; Iberian red deer had the highest titres (1:2560) for serovars Muenchen and Grippotyphosa. Pomona, the most prevalent serovar in this study, also showed high titres ( $1: 1280$ in $27.3 \%$ of positive reactions) (Supplementary Table 2 ).

The MAT is specific for the infecting serovar or closely antigenically related serovars. Sera giving positive reactions against serovar Pomona, the most frequent serovar detected in our study, were also tested against serovar Mozdok, since both serovars belong to serogroup Pomona, may cross-react and have been identified in Portugal (Rocha, 1998). All sera showed higher titres against Pomona than Mozdok.

Although many serological surveys of wildlife have been carried out, information on the seroprevalence of Leptospira spp. is limited for most species of Spanish wildlife. Differences in the prevalence of Leptospira spp. infections in different regions may reflect true variations or may result from differences in study designs, including the method of sampling, serovars included or MAT cut-off values. Pomona, one of the most prevalent leptospiral serovars in fallow deer, European wild boar and Iberian red deer in our study, has been reported in 12\% of wild boar (1:400 cut-off) in South-Central Spain (Vicente et al., 2002) and was one of the most prevalent serovars in red deer and wild boar in Croatia (Slavica et al., 2008), but was not detected in wild boar from Tuscany (Italy) (Ebani et al., 2003). Lavín et al. (1998) reported an overall Leptospira spp. seroprevalence of $12.9 \%$ in fallow deer in Spain, but did not specify the most prevalent serovars.

The fallow deer population in Asturias forms a homogeneous group restricted to an $80 \mathrm{~km}^{2}$ coastal mountain area (Sueve). In this area, after 5 years without positive reactors, we detected high prevalences against serovar Pomona in 2004 (15.2\%) and 2005 (38.1\%). In the same years, we also detected high titres (>1:1280) in several European wild boar in the region. Further studies on leptospirosis in fallow deer and European wild boar in Asturias are indicated.

\section{Conflict of interest statement}

None of the authors of this paper has a financial or personal relationship with other people or organisations that could inappropriately influence or bias the content of the paper.

\section{Acknowledgements}

This study was supported by the INIA project RTA 2006-0000500-00. We wish to thank the staff of the Consejería de Medio Ambiente for their assistance in sample collection, Francisco Javier García Peña, of the Algete (Madrid) Central Veterinary Laboratory who kindly provided some of the strains of Leptospira, Dr. Francisco Ruiz (IREC) for reviewing the document and Dr. Kevin Dalton for proof reading the text.

\section{Appendix A. Supplementary data}

Supplementary data associated with this article can be found, in the online version, at doi:10.1016/j.tvjl.2008.10.003.

\section{References}

Cole, J.R., Sulzer, C.R., Pursell, A.R., 1973. Improved microtechnique for the leptospiral microscopic agglutination test. Applied Microbiology 25, 976-980.

Ebani, V.V., Cerri, D., Poli, A., Andreani, E., 2003. Prevalence of Leptospira and Brucella antibodies in wild boars (Sus scrofa) in Tuscany, Italy. Journal of Wildlife Diseases 39, 718-722.

Espí, A., Prieto, J.M., Fernandez, M., Álvarez, M., 2000. Serological prevalence to six leptospiral serovars in cattle in Asturias (Northern Spain). Epidemiology and Infection 124, 599-602.

Espí, A., Prieto, J.M., García-Peña, F.J., 2001. Prevalencia de Leptospira interrogans serovar Bratislava en Asturias. In: Proceedings of the VII Congreso Internacional de Medicina Bovina, Oviedo, Spain, pp. 236-238.

Lavín, S., Ruiz-Bascarán, M., Marco, I.y., Viñas, L., 1998. Ecopatología del gamo (Dama dama) en el Principado de Asturias. Veterinaria, Castilla y León 9, 15-18.

León-Vizcaíno, L., Miranda, A., Perea, A., Carranza, J., Hermoso, M., 1980. Investigación inmunoserológica de diversos agentes infecciosos en ciervos y jabalíes de Sierra Morena. In: Proceedings of the II Reunión Iberoamericana de Conservación y Zoología de Vertebrados, Cáceres, Spain, pp. 490-502.

Rocha, T., 1998. A review of leptospirosis in farm animals in Portugal. Scientific and Technical Review of the OIE 17, 699-712.

SIAPA (Sistema de Información Ambiental del Principado de Asturias), 2008. Fauna protegida del Principado de Asturias. <http://www.tematico.princast.es/ mediambi/siapa/> (accessed 1.01.08).

Slavica, A., Cvetnić, Ž., Milas, Z., Janicki, Z., Turk, N., Konjević, D., Severin, K., Tončić, J., Lipej, Z., 2008. Incidence of leptospiral antibodies in different game species over a 10-year period (1996-2005) in Croatia. European Journal of Wildlife Research 54, 305-311.

Vicente, J., León-Vizcaíno, L., Gortázar, C., Cubero, M.J., González, M., Martín-Atance, P., 2002. Antibodies to selected viral and bacterial pathogens in European wild boar from southcentral Spain. Journal of Wildlife Diseases 38, 649-652. 